\title{
Extracurricular Partnerships as a Tool for Enhancing Graduate Employability
}

David I. Lewis, School of Biomedical Sciences, Faculty of Biological Sciences and University of Leeds Biosciences Education Research Group, University of Leeds, Leeds United Kingdom. Contact: $\underline{\text { d.i.lewis@leeds.ac.uk }}$

\section{ABSTRACT}

The world of work is changing rapidly, with an increasing global demand for employees with higher-level skills. Employees need to have the right attitudes and aptitudes for work, possess work-relevant skills, and have relevant experience. Whilst universities are embedding employability into their curricula, partnerships outside of the taught curriculum provide additional, largely untapped, opportunities for students to develop these key skills and gain valuable work experience. Two extracurricular partnership opportunities were created for Bioscience undergraduates at the University of Leeds, UK: an educational research internships scheme, where students work in partnership with fellow students and academic staff on on-going educational projects, and Pop-Up Science, a unique, student-led public engagement volunteer scheme. Both schemes generate substantial benefits for all. They enhance student's skills and employability, facilitate and enhance staff-student education practices and research, and engage the public with research in the Biosciences. Collectively, they demonstrate the extraordinary value and benefits accrued from developing extracurricular partnerships between students, staff, and the community.

\section{KEYWORDS}

students as partners, scholarship of teaching and learning, intern, public engagement, employability

There is an ever increasing demand within the United Kingdom labour market for employees with higher-level skills, particularly graduates from science, technology, engineering, and mathematics (STEM) disciplines (CBI \& Pearson, 2016). With the global world of work and labour markets changing rapidly, universities across the world have a critical role to play in ensuring that their graduates are workplace ready and equipped for whatever career path they 
choose to follow. Graduate recruiters require potential employees to have the right attitudes and aptitudes for work, possess work-relevant or employability skills, and have relevant work experience (CBI \& Pearson, 2015; CBI \& Pearson, 2016). With the increasing focus of students, universities, and governments on graduate employability, opportunities to gain both work experience and develop these key employability skills are increasingly being embedded within degree programmes. For example, recognising that $35 \%$ of its graduates leave science and obtain employment post graduation in non-science related careers, the School of Biomedical Sciences, University of Leeds has developed a suite of 12 different formats of final-year research projects for its students (Lewis, n.d.). Nine of these project formats are not traditionally found within science programmes; these enable students to undertake projects more closely matched to their final career destinations. The Confederation of British Industry (CBI) and Universities UK report "Future Fit: Preparing Graduates for the World of Work" (2009) recommends that educators go further, and provide opportunities outside of the taught curriculum for students to gain this work experience and develop their employability skills.

Employers expect graduates to have experience of team-working; possess problem solving, analytical and communication skills; be culturally and ethically aware; and show selfmanagement and resilience. Many of these attributes and skills are best developed through the utilisation of high-impact educational practices (Kuh, 2008) and engaged learning (Stone, 2015), for example, through working in partnership, either with fellow students or with academic staff (Crawford, Horsley, Hagyard, \& Derricot, 2015; Pauli, Raymond-Barker, \& Worrell, 2016). The formation of partnership learning communities is a concept that is becoming increasingly prevalent across the entire spectrum of higher education activities, from the assessment of learning and teaching, to curriculum design, the Scholarship of Teaching and Learning (SoTL), and subject-based research and enquiry (Healey, Flint, \& Harrington, 2014; 2016). The benefits to students and their learning experience are many and substantial. Partnerships enhance student motivation, responsibility for and engagement with learning, and provide opportunities for students to contribute to the academic community and the co-creation and sharing of knowledge (Cook-Sather, Bovill, \& Felten, 2014).

Our aim was therefore to create two novel, extracurricular, three-way partnership opportunities for undergraduate students within the Faculty of Biological Sciences:

- educational research internships comprising of partnerships between students, their fellow students, and academic staff; and

- Pop-Up Science, a public-engagement volunteer scheme, comprising a partnership between students, their fellow students, and members of the public.

\section{EDUCATIONAL RESEARCH INTERNSHIPS}

Educational research internships are a partnership between students, their peers, and academic staff, all working collaboratively, and as equals, on the academic partner's ongoing curriculum development or pedagogical research projects. Recent projects include: the collation of an online collection of open educational resources on animal experimentation (see www.etris.leeds.ac.uk; Lewis, 2014a); student-created guidance on the use of e-learning resource-development software (Lewis et al., 2015); and the evaluation of public engagement opportunities within STEM undergraduate curricula (Lewis, Gutoreva, Carlisle, Hughes, \& Black, 2014). 
Internships may be for a concentrated period or spread over the academic year, fitted around students' other academic commitments or undertaken during university vacations. Interns either work individually with their academic partner or may be part of a small team. They are recruited, following personal applications, from the Level-4 and Level-5 (first- and second-year) cohorts of students enrolled on any of the Faculty of Biological Sciences' undergraduate degree programmes. Each intern undertakes 75 hours of paid work, paid in two installments, one-third at the start of the project and two-thirds on completion. Internships are extremely popular, typically 3-4 times oversubscribed, with up to 12 interns recruited across the Faculty each year.

Internships are a true collaborative partnership between the interns and their academic partners, embodying many of the nine principles of partnership identified by Healey, Flint, and Harrington (2014) including (a) authenticity, or a real-life work experience; (b) inclusivity, or being open to all and adapted to suit different student needs or circumstances; (c) empowerment, where students have the opportunity to take ownership of their internship and to lead in its direction; (d) mutual trust between partners, involving making the most of the knowledge, skills, and attributes of each to drive the internship forward; and (e) collective responsibility for ensuring the success of the project.

Our aim is for students to get the most out of this opportunity, to reflect on and learn from their experiences, and to implement this learning in later stages of internship (Gibbs, 1988). They create personal reflective blogs for themselves; initially they reflect on their aspirations and motivation for undertaking an internship. At the end of the internship, they write a reflective case study. Participation in this scheme is recorded in their Higher Education Achievement Report (HEAR) transcripts, a university accredited record of their non-academic achievements (see www.hear.ac.uk/).

\section{POP-UP SCIENCE}

The creation of impact and engaging the public with one's research are increasingly required by funding bodies, and increasing numbers of Bioscience graduates are looking towards science communication as a career (Lewis, 2014b). However, public engagement and science communication are skills rarely taught within undergraduate Biosciences curricula in the United Kingdom. Further, business is becoming increasingly global in nature. To compete in this global marketplace, graduate employers require their employees to be ethically, socially, and culturally aware. Recognising this, the University of Leeds, with its innovative "Leeds Curriculum" (see http://ses.leeds.ac.uk/info/22222/leeds curriculum) requires all of its undergraduate programmes, irrespective of discipline, to include an education in ethics and social responsibility and to promote global and cultural insight. Institutions are increasingly developing "civic" or "engaged" curricula (Stone, 2015; 2016), where cultural and ethical awareness and the development of public engagement and communication skills are acquired through community engagement activities, service learning, and capstone projects (Oden, Epstein, \& Richards-Kortum, 2010; Budny \& Khanna, 2012). To provide these experiences and skills development to Bioscience students at the University of Leeds, Pop-Up Science, a unique, student-led, extra-curricular public-engagement volunteer scheme was created (Spurring, Bacon, Garrod, \& Lewis, 2014). 
Pop-up science volunteers work in teams to create and deliver interactive public engagement activities at local community fetes, family fun days, and agricultural shows at weekends or during University vacations. The result is a three-way partnership between students, their fellow students, and the community. They do not go into schools; instead they target "hard-to-reach" sections of the community.

Students with and without public engagement experience team up, working in partnership with each other to create and deliver an event; the experienced students providing training and mentoring for their partners in the process. At large agricultural shows, students may engage with upwards of 8,000 visitors per day, an invaluable personal experience and skills-development opportunity for them. To get the most out of their experiences, students are required to blog their reflections as to why they joined, what they hoped to get of it, and any fears they may have upon joining the partnership. They then blog again after each event they participate in.

Pop-Up Science is experiential learning at its best, with students exploring and engaging with communities, cultures, and opinions different from their own. They form partnership learning communities with the public and their peers to engage with global issues that go beyond the classroom, all of which are high-impact educational practices that have been demonstrated to enhance student learning and engagement with their discipline (Kuh, 2008; Stone, 2015). This learning is not restricted to interactions between students or to a one-way transfer of information from students to the public. By forming learning communities and engaging with the public rather than just communicating with them, students create a threeway reciprocal partnership, with each partner gaining knowledge from others, and an increased awareness of other peoples opinions and values. Blogging brings authenticity to the partnership, with each student honestly and openly reflecting not only on what they can bring to the partnership but also on what they can learn from their partners (Healey et al., 2014). They form a community of practice by taking ownership and responsibility not only for their own contributions but for the collective development and delivery of events. They trust each other to be open, honest, and inclusive by sharing knowledge, skills, and experiences and by supporting and mentoring each other in the process.

Initially, the scheme was targeted at undergraduate students; it is now open to all, from Level4 (first-year) undergraduates to post-doctoral research assistants. Realising the benefits, some principal investigators within the Faculty make it a requirement for members of their research teams to participate in the scheme. There are currently over 60 volunteers participating each year.

\section{MY PERSPECTIVE AS AN EDUCATOR}

Students have the background and experience of being a student, something I haven't been for many years. The active involvement of students as full collaborative partners, not just as sources of feedback, enhances their learning journey and educational experiences (Kuh, 2008). They are best placed to advise on student interest. They understand their own and their peers' learning needs and the support students require. They can contribute perspectives or skills that I do not possess. In turn, they develop a wide range of employability skills including team-working; data capture, analysis, and interpretation; communication skills; time and project management; problem-solving; and resilience. All of 
these skills are highly valued by employers and can be used in students' ongoing academic studies and future careers (CBI \& Pearson, 2016).

Students are an invaluable and largely untapped resource that I utilise to the full to enhance my learning and teaching practices and activities. Without educational research interns, I would not be able to undertake the volume and range of SoTL and educational research activities I do.

Similarly, Pop-Up Science is an opportunity to share my passion for public engagement with my students. It is extremely rewarding watching them develop as science engagers and learn the art of effective communication to different audiences. Initially they struggle, but with mentoring and encouragement from their fellow volunteers through the spontaneous development of inclusive and reciprocal learning partnerships (Healey et al., 2014), they soon learn this key skill, inspiring both their audience and themselves. This learning is exemplified in quotes extracted (with their consent) from their individual reflective blogs:

"A challenge making complex tasks simple, a rewarding experience" Level-6 Human Physiology student

"I gained so much from the day. I came away feeling enthused, passionate and appreciated how much I enjoyed my degree"

Level-6 Neuroscience student

Students draw on their bioscience knowledge and a wide range of personal experiences to create innovative ways of engaging lay audiences with science. For example, a game of "whispers" or "telephone", where one person whispers a message to the next person in a line of people who whispers it to their neighbour and so on, was used to explain how nerves conduct. I learn a substantial amount from these student partners, which allows me to enhance my own activities by incorporating their ideas and practices into my own.

Being young and not the archetypal image of a scientist, undergraduates make excellent role models (Sanders \& Higham, 2012). Running activities at community fetes and fun-days enables them to reach out and inspire hard-to-reach communities and those that don't normally engage with science:

"You wouldn't think a stall like this could get the kids so inspired and interested. I had to practically drag him away"

Parent, Springtime Live 2014

The exceptional feedback students receive from the public and the enjoyment they get personally from these activities develops their passion for public engagement and inspires them to participate again.

\section{STUDENTS PERSPECTIVES}

Students recognise and appreciate the benefits to be gained from working in partnership with their peers, academic staff, and the community. Quotes below, taken (with their consent) from their reflective blogs and case studies, suggest that, as with other engaged 
learning initiatives (Stone, 2015; Stone, 2016), they view these partnerships as something different from their normal educational experiences or interactions with academic staff. Here, they are equals in an inclusive partnership learning community, are empowered and trusted, and each brings their knowledge, skills, and ideas to work collaboratively towards shared goals and outcomes (Healey et al., 2014).

"Invaluable experience in being treated as a professional rather than a student" Level-5 Biochemistry student

"Enjoyed the freedom, having almost free reign to carry out project as we saw fit, pertaining to our own skills and resources"

Level-4 Biochemistry student

Students recognise the skills they are developing and the opportunity to gain valuable work experience, both fundamental requirements of graduate recruiters and therefore the significant impact participation in these initiatives has on their future employability (CBI \& Pearson, 2016; High Fliers Research, 2017):

"Brilliant experience that taught me a variety of skills. Internships set you apart from other students"

Level-5 Biology student

"Very valuable, gives undergraduates a the sense of having a job, and some sort of responsibility, good for developing all sorts of transferrable skills"

Level-5 Biochemistry student

"Should be integral part of all degree programmes"

Level-4 Medical Sciences student

This high-impact, engaged learning approach inspires them and increases their engagement with their discipline (Cook-Sather et al., 2014):

"I am honestly surprised with the amount that I'm learning."

Level-4 Neuroscience student

"Felt rewarded when children were inspired and excited by the science we were explaining. I've developed a new found interest in the science behind it" Level-5 Zoology Student

Participation in these schemes provides tangible outputs that students can showcase to employers at interviews. Students are named as co-authors on any outputs including copresenting at conferences and workshops, further enhancing their education, skills development and CVs. 
Student appreciation of the value and benefits accrued from these interventions is reflected in the exceptional demand for them: Educational research internships are typically 8times oversubscribed, and there are currently over 60 Pop-Up Science volunteers (for 20162017). Many return for a second internship or continue to participate in Pop-Up Science in subsequent years.

\section{ISSUES}

One of the issues we have encountered with these two initiatives is funding. There is limited external funding available for educational initiatives. Each internship carries a stipend of $£ 300$ whilst Pop-Up Science incurs travel, fete registration, and consumable costs. The educational research internships scheme was initially funded by the University of Leeds Academic Development Fund and the Leeds for Life Foundation, a charitable organisation that supports employability initiatives for students at the university. Now internships are requested in educational research grant applications or funded through colleagues' teaching awards and prizes. However, a longer-term source of funding is required. Pop-Up Science was established with the prize money from the award of the UK Physiological Society Otto Hutter Teaching Prize to the author of this case study. More recently, recognising the benefits to its students, itself, and the university, the Faculty now provides $£ 3000$ per annum towards its costs.

Selection of students also represents a challenge. Internships and Pop-Up Science are heavily oversubscribed. Due to capacity constraints, it is not possible to offer these opportunities to all students that apply. However, given that selection is based on a personal statement rather than on students' academic profiles, those students who these schemes seek to benefit (i.e., those committed to enhancing their employability or education), will gain a place by virtue of them writing more compelling applications.

\section{BENEFITS}

These partnerships generate substantial benefits for all involved: students, academic staff, the Faculty, university, and the public. They enable students to contribute to academic communities where they are co-producers of knowledge (Marquis et al., 2015), to utilise highimpact and engaged-learning educational practices (Kuh, 2008; Stone, 2015), to enrich student learning journeys and broadening their education and experiences, the opportunity to develop key employability or professional skills (Crawford et al., 2015; Pauli et al., 2016), and, through providing training or mentoring to their peers, the skills of others, ultimately to become more well-rounded, workplace-ready graduates (CBI \& Pearson, 2016; High Fliers Research, 2017).

"Invaluable, help students stand out in a highly competitive employment environment" Level-5 Biology student

Given the flexibility in scheduling and commitment required, these partnerships are inclusive, enabling students who have caring or other external responsibilities, which restrict their time they can engage in co- or extra-curricular activities, to gain work experience and develop employability skills.

For academic staff, student partnerships greatly facilitate their student education and public engagement activities. Students are empowered and trusted to bring knowledge, skills, 
and a different perspective to the partnership, creating change in the professional practices of staff and enhancing the latter's educational and public engagement activities (Cook-Sather, 2014). With universities increasingly expecting their student-education focused staff to engage in the Scholarship of Teaching and Learning and/or pedagogical research, working in partnership with students greatly facilitates this work (Marquis et al., 2015). For the faculty and university, partnerships enhance their students' learning experiences and employability. Partnerships are also an opportunity to showcase externally the faculty and university's excellence in student education and public engagement.

Pop-Up Science is an opportunity for the public to engage with research in the Biosciences, an area of significant and increasing interest to them (Castell et al., 2014). It is also an engaged learning approach that enables all parties to discuss science and its underlying ethical issues, creating new knowledge and understanding for all (Stone, 2015). For researchers, it provides a novel way to engage the public, particularly non-traditional or hard-to-reach audiences, with their research, which is increasingly becoming a requirement of research funding bodies. For local fete organisers and museums, it brings novelty to, and enhances, their own activities and events.

"Your volunteers were wonderful and a credit to the university" Learning and Access Officer, Armley Industrial Museum

"Thank you so much for all your hard work, providing such an exciting and interactive stand for Springtime Live"

Educational Co-ordinator, Yorkshire Agricultural Society

\section{REFLECTIONS}

This case study provides further evidence of the extraordinary benefits that partnerships bring to a student's educational experience. It also breaks new ground by taking the concept of partnership learning communities beyond the six areas outlined in the Higher Education Academy's framework for partnerships (Higher Education Academy, 2015) into public engagement, a three-way collaborative learning partnership between students, their peers and the community.

This project has been reviewed and approved by the University of Leeds Faculty of Biological Sciences Research Ethics Committee (Ref: BIOSCI 13-001).

\section{NOTE ON CONTRIBUTOR}

Dave Lewis is Senior Lecturer in Neuroscience and Bioethics at the University of Leeds. Formally an in-vivo neuroscientist, he currently focuses on developing interventions, within and outside of the taught curriculum, that enhance student employability, providing continuing professional development opportunities for researchers, and engaging the public with science and its ethical implications. 


\section{REFERENCES}

Budny, D., \& Khanna, R. (2012). Designing a service learning project for freshman engineers. Proceedings of the 15th International Conference on Interactive Collaborative Learning, IEE. doi:10.1109/ICL.2012.6402050

Castell, S., Charlton, A., Clemence, M., Pettigrew, N., Pope, S., Quigley, A., Shah, J.N., \& Silman, T. (2014). Public attitudes to science 2014. Ipsos Mori Social Research Institute Report. Retrieved from www.ipsos-mori.com/Assets/Docs/Polls/pas-2014-main-report.pdf

CBI \& Pearson. (2015). Inspiring growth: The education and skills survey 2015. Retrieved from www.cbi.org.uk/insight-and-analysis/inspiring-growth-the-education-and-skills-survey$\underline{2015 /}$

CBI \& Pearson. (2016). The right combination: CBI/Pearson education and skills survey 2016. Retrieved from www.cbi.org.uk/cbi-prod/assets/File/pdf/cbi-education-and-skillssurvey2016.pdf

CBI \& Universities UK. (2009). Future fit: Preparing graduates for the world of work (Report). Retrieved from www.universitiesuk.ac.uk/policy-andanalysis/reports/Documents/2009/future-fit-preparing-graduates-for-the-world-ofwork.PDF

Cook-Sather, A. (2014). Student-faculty partnership in explorations of pedagogical practice: A threshold concept in academic development. International Journal for Academic Development, 19(3), 186-198.

Cook-Sather, A., Bovill, C., \& Felten, P. (2014). Engaging students as partners in teaching and learning: A guide for faculty. San Francisco: Jossey-Bass.

Crawford, K., Horsley, R., Hagyard, A., \& Derricot, D. (2015). Pedagogies of partnership: What works? (Report). Retrieved from www.heacademy.ac.uk/system/files/pedagogies-ofpartnership 0.pdf

Gibbs, G. (1988). Learning by doing: A guide to teaching and learning methods. London: Further Education Unit. Retrieved from http://gdn.glos.ac.uk/gibbs/index.htm

Healey, M., Flint, A., \& Harrington, K. (2014). Engagement through partnership: Students as partners in learning and teaching in higher education. York: Higher Education Academy. Retrieved from https://www.heacademy.ac.uk/engagement-through-partnershipstudents-partners-learning-and-teaching-higher-education

Healey, M., Flint, A., \& Harrington, K. (2016). Students as partners: Reflections on a conceptual model. Teaching \& Learning enquiry, 4(2), 1-13. Retrieved from http://tlijournal.com/tli/index.php/TLI/article/view/105

Higher Education Academy. (2015). Framework for student engagement through partnership. Retrieved from www.heacademy.ac.uk/enhancement/frameworks/framework-studentengagement-through-partnership

High Fliers Research. (2017). The Graduate Market in 2017. Retrieved from www.highfliers.co.uk/download/2017/graduate market/GMReport17.pdf

Kuh, G. D. (2008). High-impact educational practices: What they are, who has access to them, and why they matter. Washington, D.C.: Association of American Colleges and Universities. Retrieved from http://provost.tufts.edu/celt/files/High-Impact-EdPractices1.pdf 
Lewis, D. I. (n.d.). Rethinking Final Year Projects and Dissertations: Creative Honours and Capstone Projects. Retrieved from https://web.archive.org/web/20150305152342/http://insight.glos.ac.uk/tli/activities/nt f/creativehops/examples/Documents/David\%20Lewis.docx

Lewis, D. I. (2014a). ETRIS: Facilitating research and training in in-vivo pharmacology. Pharmacology Matters, 7(3), 26. Retrieved from https://www.bps.ac.uk/BPSMemberPortal/media/BPSWebsite/Library/PMDecember2014.pdf?ext=.pdf

Lewis, D. I. (2014b). Enhancing employability and building bridges: Evaluation of public engagement opportunities within undergraduate STEM curricula. Retrieved from http://www.srhe.ac.uk/downloads/Lewis.pdf

Lewis, D.I., Byrne, A., Choppin, C., Davies, D., Watkins, C., Chakrabarty, S., McBurney, S., Volz, V., \& Wilshaw, S. (2015). Creating Xerte e-learning resources: An easy to use student guide. Retrieved from https://store.data.alpha.jisc.ac.uk/\#/resource/8467.

Lewis, D. I., Gutoreva, A., Carlisle, L., Hughes, E., \& Black, L. (2014). Enhancing employability and building bridges: Public engagement opportunities within STEM undergraduate degree programmes. Proceedings of the Physiological Society, 31, C75. Retrieved from http://www.physoc.org/proceedings/abstract/Proc\%20Physiol\%20Soc\%2031C75

Marquis, E., Puri, V., Wan, S., Ahmad, A., Goff, L., \& Knorr, K. (2015). Navigating the threshold of student-staff partnerships: A case study from an Ontario teaching and learning institute. International Journal for Academic Development, 21(1), 4-15. doi:

10.1080/1360144X.2015.1113538

Oden, M., Mirabal, Y., Epstein, M., \& Richards-Kortum, R. (2010). Engaging undergraduates to solve global health challenges: A new approach based on bioengineering design. Annals of Biomedical Engineering, 38(9), 3031-3041.

Pauli, R., Raymond-Barker, B., \& Worrell, M. (2016). The impact of pedagogies of partnership on the student learning experience in UK higher education. York: Higher Education Academy. Retrieved from www.heacademy.ac.uk/resource/impact-pedagogiespartnership-student-learning-experience-uk-higher-education

Sanders, J., \& Higham, L., (2012). The role of higher education students in widening access, retention and success: A literature synthesis of the Widening Access, Student Retention and Success National Programmes Archive. York: Higher Education Academy. Retrieved from www.heacademy.ac.uk/system/files/wasrs sanders.pdf

Spurring, E., Bacon, A., Garrod, F. L., \& Lewis, D. I. (2014). Pop-Up Science: A student-led public engagement volunteer scheme. Proceedings of the Physiological Society, 31, C73. Retrieved from http://www.physoc.org/proceedings/abstract/Proc\%20Physiol\%20Soc\%2031C73

Stone, B. (2015). Engaged Learning Sheffield: Co-production and community in education at the University of Sheffield. Sheffield: University of Sheffield. Retrieved from www.sheffield.ac.uk/polopoly fs/1.521092!/file/EngagedLearningSheffield.pdf

Stone, B. (2016). Facing outwards: Engaged Learning at the University of Sheffield. Sheffield: University of Sheffield. Retrieved from www.sheffield.ac.uk/polopoly fs/1.661883!/file/FacingOutwards.pdf 